Case Reports in
Gastroenterology
Case Rep Gastroenterol 2021;15:332-337

DOI: $10.1159 / 000513804$

Published online: March 11, 2021 (c) 2021 The Author(s)

Published by S. Karger AG, Basel www.karger.com/crg

This article is licensed under the Creative Commons Attribution-NonCommercial 4.0 International License (CC BY-NC) (http://www.karger.com/Services/OpenAccessLicense). Usage and distribution for commercial purposes requires written permission.

\title{
Double Pylorus in Upper Gastrointestinal Bleeding
}

\author{
Heasty Oktaricha ${ }^{a} \quad$ Muhammad Miftahussurur $^{\mathrm{b}, \mathrm{c}}$ \\ aDepartment of Internal Medicine, Faculty of Medicine, Dr. Soetomo Teaching Hospital, \\ Universitas Airlangga, Surabaya, Indonesia; ${ }^{b}$ Division of Gastroentero-Hepatology, \\ Department of Internal Medicine, Faculty of Medicine, Dr. Soetomo Teaching Hospital, \\ Universitas Airlangga, Surabaya, Indonesia; 'Institute of Tropical Disease, Universitas \\ Airlangga, Surabaya, Indonesia
}

\section{Keywords}

Double pylorus · Gastric ulcer · NSAIDs · Diabetes mellitus · Esophagogastroduodenoscopy

\begin{abstract}
Double pylorus, also known as acquired double pylorus, is a rare condition defined as a gastrointestinal fistula connecting stomach antrum and duodenal bulb. The prevalence of double pylorus ranges from 0.001 to $0.4 \%$ by esophagogastroduodenoscopy (EGD). Although the etiology is unknown, the formation of double pylorus is related to Helicobacter pylori infection and the use of non-steroidal anti-inflammatory drugs (NSAID). The development of the occurrence of double pylorus is still unknown, but many systemic diseases play a role. We present the case of a 59-year-old man who was admitted to Dr. Soetomo General Hospital with hematemesis and melena. The patient had a history of diabetes mellitus since 3 years and consumption of medicinal herbs for myalgia, which was suspected of NSAIDs for the past 5 months. The patient had anemia with hemoglobin at $8.3 \mathrm{~g} / \mathrm{dL}$, enterogenous azotemia with blood urea nitrogen $28 \mathrm{mg} / \mathrm{dL}$ and serum creatinine $1.14 \mathrm{mg} / \mathrm{dL}$. At EGD, double pylorus was found and accompanied by gastric ulcer, a giant white base ulcer, part of it covered by clotting without any sign of active bleeding. Biopsy revealed chronic inactive gastritis, and no H. pylori was found. Treatment mainly depends on gastrointestinal acid suppression through a proton pump inhibitor (PPI). The patient was given a high-dose PPI and a mucosal protective agent. He was treated for 1 week and had improved complaints.




\section{Case Reports in Gastroenterology}

\begin{tabular}{l|l}
\hline Case Rep Gastroenterol 2021;15:332-337 \\
\hline DOI: 10.1159/000513804 & $\begin{array}{l}\text { @ 2021 The Author(s). Published by S. Karger AG, Basel } \\
\text { www.karger.com/crg }\end{array}$ \\
\hline
\end{tabular}

Oktaricha and Miftahussurur: Double Pylorus in Upper Gastrointestinal Bleeding

\section{Introduction}

Double pylorus, also known as acquired double pylorus, is a rare condition that is defined as a gastrointestinal fistula connecting stomach antrum and duodenal bulb, which was first reported by Smith and Tuttle in 1969 [1-3]. Double pylorus can occur as a congenital disorder that can be accompanied by other congenital abnormalities, which were reported by Christine in $1971[4,5]$. Double pylorus is a very rare disorder $[3,6]$. The frequency of double pylorus varies from 0.001 to $0.4 \%$ by upper gastrointestinal tract esophagogastroduodenoscopy (EGD) examination $[2,4,7,8]$. Cases are reported mainly in Asian countries and are more common in men than women [9]. For the prevalence in Indonesia, no supporting data have been found.

Though etiology is uncertain, the development of double pylorus is associated with Helicobacter pylori infection and the use of non-steroidal anti-inflammatory drugs (NSAID) [9]. In most cases, the double pylorus is a complication of chronic peptic ulcer. The double pylorus diagnosis is essential because it can be caused by recurrent ulceration and failure of epithelial formation in the fistula duct. Double pylorus development is still unknown, but many systemic diseases play a role $[10,11]$. In congenital double pylorus, defects occur in formation of pyloric ducts in the embryonic phase [5].

Double pylorus has no pathognomonic signs and symptoms. Usually, there are symptoms of dyspepsia such as epigastric pain, nausea, vomiting, bloating and gastrointestinal bleeding. Double pylorus is nevertheless identified only incidentally during EGD examination $[12,13]$. The treatment is focused on factors that influence the healing process of mucosa in gastric ulcer. Surgery on patients with refractive symptoms such as recurrent ulcers, proton pump inhibitor (PPI), and gastric obstruction is performed [14].

\section{Case Presentation}

A male 59-year-old patient was admitted to the Dr. Soetomo General Hospital with hematemesis and melena. The patient complained of hematemesis for $6 \mathrm{~h}$ before admission. He vomited three times with an amount of $200-300 \mathrm{~mL}$ and had lower abdominal pain. Defecate black liquid twice since $6 \mathrm{~h}$ before admission with a very bad smell. The patient complained of dizziness accompanied by nausea and had no appetite since 5 days. There had been shortness of breath when performing heavy activity, reduced when resting and absence of fever.

The patient had a history of diabetes mellitus since 3 years. He was under insulin and oral medication but irregularly. History of hypertension, heart, lung, and kidney diseases was denied. There was a history of consuming medicinal herbs for myalgia. The patient consumed it every day. He felt weak when he did not drink. He used this drug for the past 5 months. Psychosocial history: he works as a construction worker and is smoking three packs a day since youth.

On physical examination, it was found with compos mentis GCS 456 that his blood pressure was $125 / 75 \mathrm{~mm} \mathrm{Hg}$, heart rate was $96 \times /$ min regular, strong pulse, adequate content, respiratory rate was $20 \times / \mathrm{min}$, the axillary temperature was $36.5^{\circ} \mathrm{C}$, and $\mathrm{SpO} 2$ was $99 \%$ of free air. The examination of head and neck conjunctiva anemic was present, no jaundice, no cyanosis, no dyspnea, no enlarged lymph nodes, jugular venous pressure does not increase. The thorax was normal, the abdomen appeared flat and there was no palpable mass, liver and spleen enlargement were not palpable, he had normal bowel sounds, and abdominal pain in

\section{Karger'=}




\section{Case Reports in Gastroenterology}

Case Rep Gastroenterol 2021;15:332-337 DOI: $10.1159 / 000513804$

(c) 2021 The Author(s). Published by S. Karger AG, Basel www.karger.com/crg

Oktaricha and Miftahussurur: Double Pylorus in Upper Gastrointestinal Bleeding

the umbilical region. Extremities were warm, dry acral, capillary refill time $<2$ s. No edema was found on both legs.

Laboratory tests showed that his $\mathrm{Hb}$ was $8.3 \mathrm{~g} / \mathrm{dL}$, hematocrit was 23.6\%, MCV 78.1; $\mathrm{MCH}$ 27.5; MCHC 35.2; platelets were $356,000 \mathrm{~mm}^{3}$, leukocytes were $14,369 \mathrm{~mm}^{3}$, neutrophils were $79.1 \%$, lymphocytes were $14.5 \%$, sodium was $132 \mathrm{mmol} / \mathrm{L}$, potassium was $4.4 \mathrm{mmol} / \mathrm{L}$, chloride was $106 \mathrm{mmol} / \mathrm{L}, \mathrm{HbA1C}$ was 11.2\%, random blood sugar was $202 \mathrm{mg} / \mathrm{dL}$, SGOT was 16 U/L, SGPT was $27 \mathrm{U} / \mathrm{L}$, blood urea nitrogen (BUN) was $28 \mathrm{mg} / \mathrm{dL}$, serum creatinine was 1.14 $\mathrm{mg} / \mathrm{dL}$, and albumin was $3 \mathrm{~g} / \mathrm{dL}$. The examination of chest radiograph showed normal heart and lungs.

The patient was treated with a B1 soft diet 2,100 kcal/day, infusion of $\mathrm{NaCl} 0.9 \%$ 1,500 $\mathrm{mL}$ in $24 \mathrm{~h}$ i.v., injection of omeprazole $40 \mathrm{mg}$ every $8 \mathrm{~h}$ i.v., sucralfat syrup $15 \mathrm{~mL}$ every $8 \mathrm{~h}$ orally, novorapid injection 4 units every $8 \mathrm{~h} \mathrm{sc}$ ac $15 \mathrm{~min}$, transfusion of packed red cells (PRC) $1 \mathrm{bag} /$ day until $\mathrm{Hb}>10 \mathrm{~g} / \mathrm{dL}$, metoclopramide $10 \mathrm{mg}$ every $8 \mathrm{~h}$ i.v., amlodipin $10 \mathrm{mg}$ every 24 $\mathrm{h}$ orally, lactulac syrup $15 \mathrm{~mL}$ every $8 \mathrm{~h}$ orally, Ceftriaxon $1 \mathrm{~g}$ every $12 \mathrm{~h}$ i.v., and paracetamol $500 \mathrm{mg}$ every $8 \mathrm{~h}$ orally.

The patient had been given PRC transfusion until $\mathrm{Hb}$ reached $10.3 \mathrm{~g} / \mathrm{dL}$, and the upper gastrointestinal EGD showed that the cause of bleeding to this patient was a gastric ulcer which was suspected and caused by consumption of medicinal herbs. At EGD, double pylorus was accompanied by giant white ulcer with a partially covered in clotting without any sign of active bleeding. It could be concluded that there was a double pylorus with giant ulcer, Forrest IIb (Fig. 1).

After 1 week of treatment at Dr. Soetomo General Hospital, the patient's complaints were improved and he had no nausea nor vomiting, there were no hematemesis and melena, and his appetite was improved. The patient was discharged from hospital. Planning therapy was B1 soft diet 2,100 kcal/day, omeprazole $20 \mathrm{mg}$ every $12 \mathrm{~h}$ per oral, sucralfat syrup $15 \mathrm{~mL}$ every $8 \mathrm{~h}$ orally, novorapid injection 4 units every $8 \mathrm{~h} \mathrm{sc}$ ac 15 min, amlodipin $10 \mathrm{mg}$ every 24 $\mathrm{h}$ orally. Biopsy revealed chronic inactive gastritis, and no $H$. pylori was detected. The patient underwent checkup at the Gastroenterology department after 1 week of hospital discharge with complaints of decreased appetite, abdominal pain, and no nausea and received sucralfate syrup and lansoprazole orally.

\section{Discussion/Conclusion}

Most of the double pylorus cases reported previously occurred in Asian countries and have become case reports in the world including Greece and Peru [3, 9]. In the world literature, less than 100 cases have been reported and most patients are European or Asian. Only five cases were registered in the US [14]. The mechanism for occurrence of double pylorus is still unknown. A long history of treatment, including NSAIDs and corticosteroids, can influence peptic ulcer healing. As a potential ulcerogenic drug, NSAIDs play an important role in formation of double pylorus $[3,4,6,15]$. Double pylorus is associated with comorbid diseases that accompany it. Many systemic diseases play a role in poor healing, for example diabetes mellitus. In diabetes mellitus, damage to the gastric mucosal microcirculation can be a cause. Poor healing is also associated with other diseases, such as chronic blockage of the lungs, chronic renal failure, rheumatoid arthritis, and systemic lupus erythematosus $[2,4,6]$. The cause of poor healing may be due to nonadherence and no affordability of treatment or

\section{Karger'=}




\section{Case Reports in Gastroenterology}

Case Rep Gastroenterol 2021;15:332-337

DOI: $10.1159 / 000513804$

(c) 2021 The Author(s). Published by S. Karger AG, Basel www.karger.com/crg

Oktaricha and Miftahussurur: Double Pylorus in Upper Gastrointestinal Bleeding

NSAIDs [14]. The patient had a history of consumption of medicinal herbs which was suspected of NSAIDs. He took it for 5 months and had a history of diabetes mellitus since 3 years.

There are no specific clinical symptoms of double pylorus. Symptoms include chronic stomach pain, dyspepsia and vibrations and gastrointestinal bleeding due to peptic ulcer or other diseases [1, 2, 4]. Although the entire blood and blood count is generally normal, full blood tests indicate anemia in patients with gastrointestinal bleeding and biochemistry will increase enterogenous azotemia ureum nitrogen with regular serum creatinine [2]. The patient had anemia with $\mathrm{Hb}$ at $8.3 \mathrm{~g} / \mathrm{dL}$, enterogenous azotemia with BUN $28 \mathrm{mg} / \mathrm{dL}$ and serum creatinine $1.14 \mathrm{mg} / \mathrm{dL}$.

Diagnosis of double pylorus is made by EGD. Mostly, double pylorus is located in the minor curvatura of the gastric antrum. From the gastric antrum, visualization of biopsy forceps or catheters that have passed through double pylorus and entered the pylorus can be described as a technique to diagnose double pylorus $[1,15]$. In a patient with double pylorus, a research for $H$. pylori is very important. Some literature has shown that there is a correlation between the occurrence of double pylorus and $H$. pylori. Patients infected with $H$. pylori should be treated [2]. During treatment, EGD showed that the cause of bleeding in the patient was a gastric ulcer which was suspected and caused by consumption of medicinal herbs for myalgia. At EGD (Fig. 1), double pylorus was accompanied by a giant white ulcer which was partially covered in clotting without any sign of active bleeding. There was a double pylorus with giant ulcer Forrest IIb. Biopsy revealed chronic inactive gastritis and no H. pylori was found.

In general, double pylorus is a by-product of upper gastrointestinal EGD. Most dual pylorus lie on the side of the minor curvatura between the gastric antrum and the superior part of the duodenal bulb $[3,12]$. It is believed that fistula formation due to gastric ulcer causes anomalies, but duodenal ulcer can also cause the formation of double pylorus [3]. In our patient with double pylorus that was found incidentally during EGD, the double pylorus was located in the gastric side of curvature on the minor side.

The management should focus on factors that inhibit mucosal healing. NSAIDs and corticosteroids should be avoided. In the majority of patients, double pylorus has good response to medical treatments, such as PPIs, $\mathrm{H}_{2}$ antagonist receptors, antacids and mucosal protective agents, both regardless of whether double pylorus persists or not. Cessation of NSAID use is very beneficial because symptoms will be reduced, recurrence of ulcers can be prevented, and the double pylorus will close [1-3]. Surgical intervention is not primary therapeutic [1-3]. According to a retrospective study, in double pylorus treated with antagonists $\mathrm{H}_{2}$ receptor or PPI, the double pylorus remains open in the majority of patient by $64 \%$, merges with normal pylorus in $27 \%$ and closes in only $9 \%$ of cases [4, 8]. Complications are gastric outlet obstruction and persistent gastric ulceration [4]. Treatment mainly depends on gastrointestinal acid suppression through PPI. In the current case, the patient was given a high-dose PPI and a mucosal protective agent. In the development of ulcers and chronic ulcers, $H$. pylori played a significant role. However, we did not notice $H$. pylori in the current case in the biopsy specimen. Patients should be followed up and EGD repeated to assess improvement of ulcers and whether double pylorus remains open, fused with normal or closed pylorus.

In conclusion, we reported the case of a 59-year-old man who presented with hematemesis and melena. Laboratory tests showed decreased $\mathrm{Hb}$ and increased BUN. The results of EGD confirmed that the cause of bleeding was peptic ulcers caused by excessive consumption of medicinal herbs. In EGD, double pylorus in the upper gastrointestinal tract with giant ulcer Forrest IIb without any sign of active bleeding was detected. The biopsy showed chronic

\section{Karger'"}




\section{Case Reports in Gastroenterology}

\begin{tabular}{l|l}
\hline DOI: $10.1159 / 000513804$ & ○ 2021 The Author(s). Published by S. Karger AG, Basel
\end{tabular} www.karger.com/crg

Oktaricha and Miftahussurur: Double Pylorus in Upper Gastrointestinal Bleeding

inactive gastritis and no H. pylori was found. The patient was given high doses of PPI and mucosal protective agents.

\section{Statement of Ethics}

Written informed consent for this case report was obtained from the patient for publication.

\section{Conflict of Interest Statement}

The authors have no conflicts of interest to declare.

\section{Funding Sources}

There are no funding sources to report.

\section{Author Contributions}

Heasty Oktaricha, Muhammad Miftahussurur performed data acquisition and drafted the manuscript. Muhammad Miftahussurur supervised and provided critical revision of the manuscript. All authors read and approved the final manuscript.

\section{References}

1 Chen QY, Chen Y, Liang, Wang J, Du Q, Cai JT, et al. Acquired double pylorus: a case report. Asian Pac J Trop Med. 2012 Jun;5(6):503-4.

2 Lei JJ, Zhou L, Liu Q, Xu CF. Acquired double pylorus: clinical and endoscopic characteristics and four-year follow-up observations. World J Gastroenterol. 2016 Feb;22(6):2153-8.

3 Sevinç B. Double pylorus; a Rare Disorder Presenting with Gastrointestinal Bleeding. Int J Surg Transplant Res. 2017;1(1):5-6.

4 Fousekis F, Aggeli P, Kotsaftis P, Pappas-Gogos G. Double Pylorus: Report of a Case With Endoscopic FollowUp and Review of the Literature. Gastroenterol Res. 2018 Apr;11(2):154-6.

5 Seyyedmajidi M, Shajari R, Vafaeimanesh J. An interesting finding in upper gastrointestinal endoscopy. Middle East J Dig Dis. 2020 Apr;12(2):130-2.

6 Tseng CW, Tsai JJ, Lin HJ. Double pylorus: an unusual complication of peptic ulcer disease (with video). Clin Gastroenterol Hepatol. 2008 Oct;6(10):e38.

7 Taş A, Yeșil Y, Beyazt Y, Köklü S. A rare endoscopic finding in an elderly patient: double pylorus. Int J Gerontol. 2012;6(3):234-5.

8 Thapa SS, Scott J. Double pylorus. BMJ Case Rep. 2018 Sep;2018:1-2.

9 Deshmukh F, Devani K, Francisco P, Merrell N. Gastroduodenal Fistula: A Rare Finding With an Atypical Presentation. Gastroenterol Res. 2020 Jun;13(3):121-4.

10 Akazawa Y, Mizuta Y, Osabe M, Nakamura T, Morikawa S, Isomoto H, et al. A case of double pylorus caused by recurrent gastric ulcers: a long-term endoscopic observation. Dig Dis Sci. 2005 Nov;50(11):2125-8.

11 Kane LA, Stanich PP, Oza VM. Double pylorus sign. Indian J Gastroenterol. 2015 Jan;34(1):92.

12 Keskin. Double Pylorus: An Uncommon Endoscopic Finding. J Med Cases. 2012;3(3):172-3.

13 Mahmoud S, Soltany A. A rare case report of gastro-duodenal fourth segment fistula secondary to a penetrating benign gastric ulcer. J Surg Case Rep. 2019 Apr;2019(4):rjz096. https://doi.org/10.1093/jscr/rjz096.

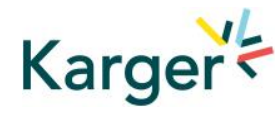


Case Reports in Gastroenterology
Case Rep Gastroenterol 2021;15:332-337

DOI: 10.1159/000513804

(c) 2021 The Author(s). Published by S. Karger AG, Basel www.karger.com/crg

Oktaricha and Miftahussurur: Double Pylorus in Upper Gastrointestinal Bleeding

14 Atiq 0, Abrams GA. CASE STUDY IN GASTROENTEROLOGY \& HEPATOLOGY: An Uncommon Complication of Peptic Ulcer Disease. Gastroenterol Hepatol (N Y). 2014 May;10(5):333-4.

15 Akbulut S, Erten A, Özaslan E, Altıparmak E. Double pylorus. Balkan Med J. 2014 Jun;31(2):187-8.

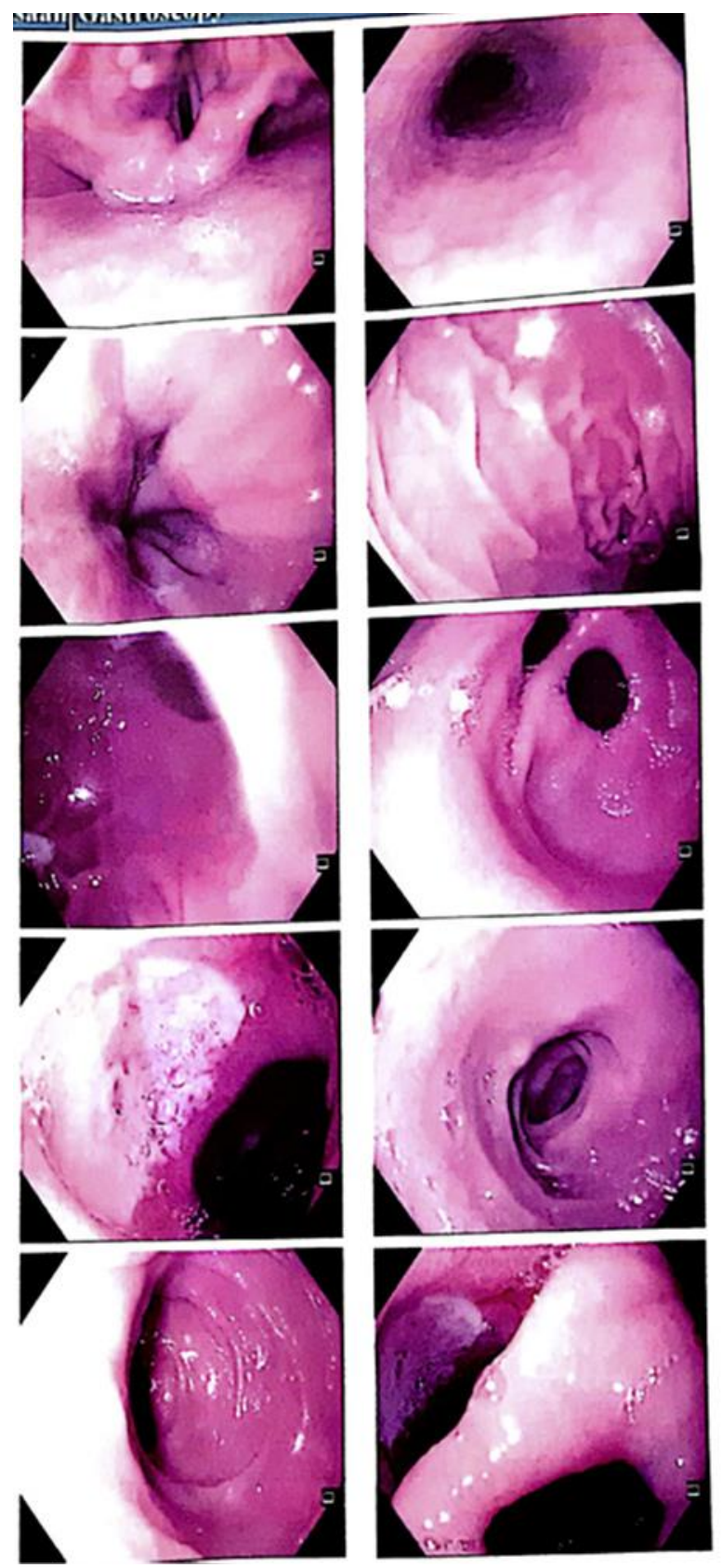

Fig. 1. Double pylorus is shown. 